\title{
Changes in prey importance and prey niche overlap of sexes during the alpine newt breeding season
}

\author{
Oldřich Kopecký
}

\begin{abstract}
Department of Zoology and Fish Farming, Faculty of Agrobiology, Food and Natural Resources, Czech University of Life Sciences in Prague, Kamýcká 129, Prague 6-Suchdol 165 21, Czech Republic.

Email: kopeckyo@af.czu.cz
\end{abstract}

\begin{abstract}
Urodeles, including European newts, are usually sexually dimorphic predators. Among newts, the alpine newt has the most pronounced sexual size dimorphism (in favour of females). Gender is a factor that is often associated with intra-specific diet differences. Despite the significant number of dietary studies on the alpine newt, some topics such as the breadth of the trophic niche and its overlap between sexes, or inter-sexual differences in qualitative and quantitative composition of prey remain unresolved. The present study dealing with these questions was conducted at two localities (ponds at an elevation of about $450 \mathrm{~m}$ ) in the Czech Republic. Newts were captured from the banks during the entire breeding season using a dip net, and the stomach contents were extracted using a stomach flushing technique. Altogether 190 individuals were sampled, and a total of 1,417 prey items were obtained. The available food sources differed over the course of the breeding season, as newts changed the taxa they preyed on. This reflects the ability of newts to switch between several hunting strategies. The overall food niche overlap between the sexes was relatively large $(\mathrm{C}=$ 0.761 , resp. $\mathrm{C}=0.797$ ). Inter-sexual differences were detected at both localities, mainly in the number of prey items consumed from the most important prey categories such as Rana eggs or Isopoda, which were consumed in higher numbers by females. The findings of this study suggest that females are more sensitive to the trade-off between energy intake and expenditure during the breeding season.
\end{abstract}

KEY WORDS: Amphibia, Caudata, food, foraging, diet

\section{INTRODUCTION}

For many predators, including amphibians, our understanding of what is eaten, how the diet is influenced by foraging behaviour, and the consequences of the diet and foraging in relation to body condition is limited. This is partly due to the fact that predator diets are influenced by individual factors such as age, size or sex, and simultaneously by factors of their environment such as prey size, diversity and abundance, the last two of which are often difficult to measure (BECK et al., 2007).

Sexual size dimorphism is an intrinsic factor that is often associated with intra-specific diet differences (SHETTY \& SHINE, 2002; BLACKENHORN, 2005; ZALEWSKI, 2007). In turn, inter-sexual resource partitioning can itself directly lead to sexual size dimorphism (SHINE, 1989; KRÜGER, 2005).

Sexual size dimorphism has also been reported for European newts, and among them the one with the most pronounced sexual size dimorphism is the alpine newt (Ichthyosaura alpestris) where females are significantly larger than males (DENOËL et al., 2009). The alpine newts have a multiphasic life cycle - seasonally changing between aquatic and terrestrial environments. During their aquatic phase they reproduce (GRIFFITHS, 1996). Newts concentrate in lentic waters at higher densities than they do in the terrestrial environment, and catching them in water is easier (HOECK \& GARNER, 2007). Therefore, most studies of newt ecology, including feeding ecology, are realized during their breeding period. When living syntopically 
Alpine newts stay in the water for a shorter time than other species (COVACIU-MARCOV et al., 2010).

Newts are able to hunt prey just as effectively on land as in the water (HeIsS et al., 2013). The availability and consequent importance of prey items is specific according to the locality (e.g. RulíK, 1993; DENOËL \& ANDREONE, 2003). Densities and composition of prey are not stable over the season and can vary significantly over the course of the breeding period (SCHABETSBERGER \& JERSABEK, 1995; DENOËL \& DEMARS, 2008). It is therefore important to examine the entire breeding period to obtain a complete picture of newt prey composition.

In previous studies on the diet of alpine newts in the Czech Republic, we dealt with non-prey items (KOPECKÝ et al., 2011), scaling of prey between the sexes during the breeding season (KOPECKÝ et al., 2012a) and with the composition of the diet during spring migration (KOPECKÝ, accepted). The present study uses the same dataset as previously published studies, and by highlighting two so-far neglected topics prey change and dietary overlap of the sexes completes a picture of the alpine newt's diet. Therefore aims of this paper are to i) analyse the breadth of the trophic niche and its overlap between the sexes; ii) determine inter-sexual differences in amount of consumed prey from various taxa; and iii) detect changes of consumed prey over time.

\section{MATERIAL AND METHODS}

The study was conducted at two localities in the Czech Republic near the town of Ledeč nad Sázavou. Both sites lie at an elevation of about $450 \mathrm{~m}$. The first, hereafter referred to as locality A $\left(49^{\circ} 42^{\prime} 45^{\prime \prime} \mathrm{N}, 15^{\circ} 16^{\prime} 50^{\prime \prime} \mathrm{E}\right)$, is a fishless pond with a surface area of $36.0 \mathrm{~m}^{2}$ and a maximum depth of $0.8 \mathrm{~m}$. The pond's banks are planted with willows (Salix sp.), and the pond is surrounded by a pasture. The bottom is muddy, and vegetation in the water is scant, consisting mainly of common duckweed (Lemna minor), startwort (Callitriche verna) and compact rush (Juncus conglomeratus). The pond is artificial, its original purpose being to drain water from surrounding pastures. The water's $\mathrm{pH}$ values ranged from 6.5 to 7.0 during the study.

The second locality, designated as locality B $\left(49^{\circ} 44^{\prime} 24^{\prime \prime} \mathrm{N}, 15^{\circ} 16^{\prime} 59^{\prime \prime} \mathrm{E}\right)$, is a now-fishless pond that was historically used for fish rearing. Pond $\mathrm{B}$ is situated in a spruce forest. It has a surface area of $27.5 \mathrm{~m}^{2}$ and maximum depth of $0.3 \mathrm{~m}$. The pond's bottom is muddy. Water plants, consisting mainly of common waterweed (Elodae canadensis), startwort (Callitriche verna) and reed mannagrass (Glyceria aquatica), cover a large part of the pond's surface area. During the study, $\mathrm{pH}$ values were around 5.5.

Alpine newts are the dominant amphibian species at both localities, where a small number of smooth newts (Lissotriton vulgaris) and common frogs (Rana temporaria) also regularly reproduce. Adult alpine newts were caught during the entire breeding season from the banks using a dip net. Sampling was done during daylight hours: once in April, once in May and once in June 1997. The newts were kept in a container filled with water from the pond and marked (HEYER et al., 1994) by toe-clipping (FERNER, 1979). To avoid data dependence (LUISELLI et al., 2007), only the newts captured for the first time were used in the study. Stomach contents were extracted using the stomach flushing technique described by OPATRNÝ (1980). The newts were not anaesthetized and were released back into the water immediately after these procedures.

The stomach contents were individually stored in vials and preserved in 4\% formaldehyde. Prey items were identified using a stereo microscope. Due to the technical impossibility of weighing all the prey items obtained (1417), only representative samples of each taxa (cca 15\% from all prey items) were weighed. Obtained weights were verified by previously published work (OPATRNÝ, 1968). Based on this approach four biomass categories were defined: $0.001 \mathrm{~g}$ 
for Megaloptera-larvae, Cladocera, Cyclopoida, Turbellaria; $0.01 \mathrm{~g}$ for Chironomidae-larvae, Chironomidae-pupae, Culicidae-pupae, Bivalvia, Gastropoda, Dytiscidae-larvae; $0.1 \mathrm{~g}$ for Ephemeroptera-larvae, Ephemeropterapupae, Lepidoptera-larvae, Plecoptera-larvae, Trichoptera-larvae, Arachnida, Isopoda, Ranaeggs, and $1 \mathrm{~g}$ for Lumbricus.

The index of relative importance (IRI) and IRI\% for each taxon (i) were computed following MARIANO-JELICICH et al. (2007) as:

$$
\begin{aligned}
\operatorname{IRI}_{\mathrm{i}} & =\mathrm{f}_{\mathrm{i}} \%\left(\mathrm{n}_{\mathrm{i}} \%+\mathrm{m}_{\mathrm{i}} \%\right) \\
\text { IRI }_{\mathrm{i}} \% & =\left(\text { IRI }_{\mathrm{i}} \cdot 100\right) / \mathrm{IRI}_{\text {total }},
\end{aligned}
$$

where $\mathrm{f} \%$ is the percentage of newts containing a particular taxon $\left({ }_{i}\right), n \%$ is the percentage of prey items of a particular taxon $\left(_{i}\right.$ ) out of all prey items, and $\mathrm{m} \%$ is the percentage of biomass provided by a particular taxon $\left(_{i}\right.$ ) out of the estimated total biomass consumed.

Trophic niche overlap using Schoener index (KREBS, 1998) was calculated as:

$$
\mathrm{C}=1-0.5\left(\Sigma_{\mathrm{i}}\left|\mathrm{p}_{\mathrm{xi}}-\mathrm{p}_{\mathrm{yi}}\right|\right),
$$

where $p_{x i}$ is the proportion of taxon $\left(_{i}\right)$ in sex $\left({ }_{x}\right)$ and $\mathrm{p}_{\mathrm{yi}}$ is the proportion of taxon $\left(_{\mathrm{i}}\right)$ in $\operatorname{sex}\left({ }_{\mathrm{y}}\right)$.

Food niche breadth was calculated by Levins' index (KREBS, 1998) as:

$$
\mathrm{B}_{\mathrm{A}}=(\mathrm{B}-1) /(\mathrm{n}-1),
$$

where $\mathrm{B}_{\mathrm{A}}$ is the standardized Levins' index by the number of available items $n$ :

$$
\mathrm{B}=1 / \Sigma \mathrm{p}_{\mathrm{i}}^{2} \text {, }
$$

where $\mathrm{p}_{\mathrm{i}}$ is proportion of taxon in overall $\operatorname{diet}\left(_{\mathrm{i}}\right.$ ).

Mann-Whitney U-tests were used for comparing number of consumed prey items between sexes. Calculations were performed in Statitistica 12 software (Statsoft 2012). Statistical significance was determined at the level $\alpha=0.05$.

\section{RESULTS}

During the three study months, a total of 190 newts were sampled (locality A: 47 males, 50 females; locality B: 54 males, 39 females), from which a total of 1,417 prey items were obtained.
Based on pooled sample data (sexes and months together) the most consumed prey based on IRI\% were Cladocera at locality A and Isopoda at locality B. The importance of food resources was not stable during the breeding season, and shifts among prey categories were considerable (Fig. 1).

The total number of prey items eaten throughout the season from a particular taxon was, with some exceptions, the same for males and females at locality A (Table 1), just as it was at locality B (Table 2). If sampling time is considered, there was no inter-sexual difference in the consumption of any prey category in April, May or in June at locality B. At locality A, females consumed more Rana-eggs during April (males: mean $=0.31$, $\min .-\max .=0-3$; females: mean $=1.10$, min. $-\max .=0-4$; U-test: $Z=2.13$, $\mathrm{P}<0.05)$. During June, females consumed more Gastropods (males: mean $=0$; females: mean $=$ 0.35, min. - max. $=0-2$; U-test: $\mathrm{Z}=-2.09, \mathrm{P}<$ 0.05 ) and Cladocera (males: mean $=9.75$, min. max. $=0-45$; females: mean $=38.5$, $\min .-\max .=$ 0-114; U-test: $\mathrm{Z}=-2.68, \mathrm{P}<0.01)$.

The overall food niche overlap of sexes (based on $\mathrm{n} \%)$ was quite large at locality $\mathrm{A}(\mathrm{C}=0.761)$ as well as at locality $\mathrm{B}(\mathrm{C}=0.797)$. Niche overlap was relatively stable throughout the breeding season at locality $\mathrm{B}$ (April, $\mathrm{C}=0.895$; May, $\mathrm{C}=$ 0.833; June, $\mathrm{C}=0.868)$, while at locality A there was an apparent increase in overlap in June (April, $\mathrm{C}=0.624$; May, $\mathrm{C}=0.678$; June, $\mathrm{C}=0.896$ ).

Levin's niche breadth changed during the breeding season. At locality A niche breadth was widest at the start of the season (in April) for both sexes, whereas at locality B the opposite was true and breadth was widest in June (Table 3).

\section{DISCUSSION}

Breeding alpine newts prey on a wide variety of organisms. Generally, Chironomidae larvae (ROČEK et al., 2003; DENOËL \& ANDREONE, 2003), Cladocera (Joly \& GiACOMA, 1992) and 
TABLE 1

Differences in the number of consumed prey items between sexes of alpine newt from locality A (data from the months April, May, June pooled).

\begin{tabular}{lcccc}
\hline Prey & M mean (min. -max.) & F mean (min. -max.) & $\mathbf{Z}$ & $\mathbf{P}$ \\
\hline Turbellaria & $0.13(0-1)$ & $0.26(0-1)$ & 1.63 & 0.10 \\
Oligochaeta & $0.06(0-1)$ & $0.18(0-1)$ & -1.72 & 0.09 \\
Gastropoda & $0.02(0-1)$ & $0.16(0-2)$ & -1.88 & 0.07 \\
Bivalvia & $0.09(0-3)$ & $0.04(0-1)$ & 0.07 & 0.94 \\
Arachnida & 0.00 & 0.00 & & \\
Cladocera & $3.32(0-45)$ & $15.40(0-114)$ & -1.73 & 0.08 \\
Cyclopoida & $\mathbf{0 . 1 7}(\mathbf{0 - 1})$ & $\mathbf{0 . 0 6}(\mathbf{0 - 2})$ & $\mathbf{2 . 0 3}$ & $\mathbf{0 . 0 4}$ \\
Isopoda & $0.09(0-1)$ & $0.08(0-1)$ & 0.08 & 0.93 \\
Ephemeroptera larvae & $0.09(0-3)$ & $0.16(0-2)$ & -1.34 & 0.18 \\
Ephemeroptera pupae & 0.00 & $0.12(0-5)$ & -1.36 & 0.17 \\
Plecoptera nymfa & $0.23(0-3)$ & $0.22(0-3)$ & 0.35 & 0.73 \\
Megaloptera larvae & $0.04(0-1)$ & $0.02(0-1)$ & 0.63 & 0.53 \\
Trichoptera & $0.06(0-1)$ & $0.04(0-1)$ & 0.52 & 0.60 \\
Lepidoptera & $0.06(0-2)$ & 0.00 & 1.45 & 0.15 \\
Culicidae pupae & $0.02(0-1)$ & 0.00 & 1.01 & 0.31 \\
Chironomidae larvae & $0.66(0-7)$ & $0.48(0-6)$ & 0.86 & 0.39 \\
Chironomidae pupae & $0.17(0-2)$ & $0.48(0-5)$ & -0.82 & 0.42 \\
Coleoptera & $0.02(0-1)$ & $0.02(0-1)$ & 0.03 & 0.98 \\
Rana eggs & $\mathbf{0 . 1 7}(\mathbf{0 - 3})$ & $\mathbf{0 . 5 8}(\mathbf{0 - 7})$ & $\mathbf{- 2 . 2 4}$ & $\mathbf{0 . 0 3}$ \\
\hline
\end{tabular}
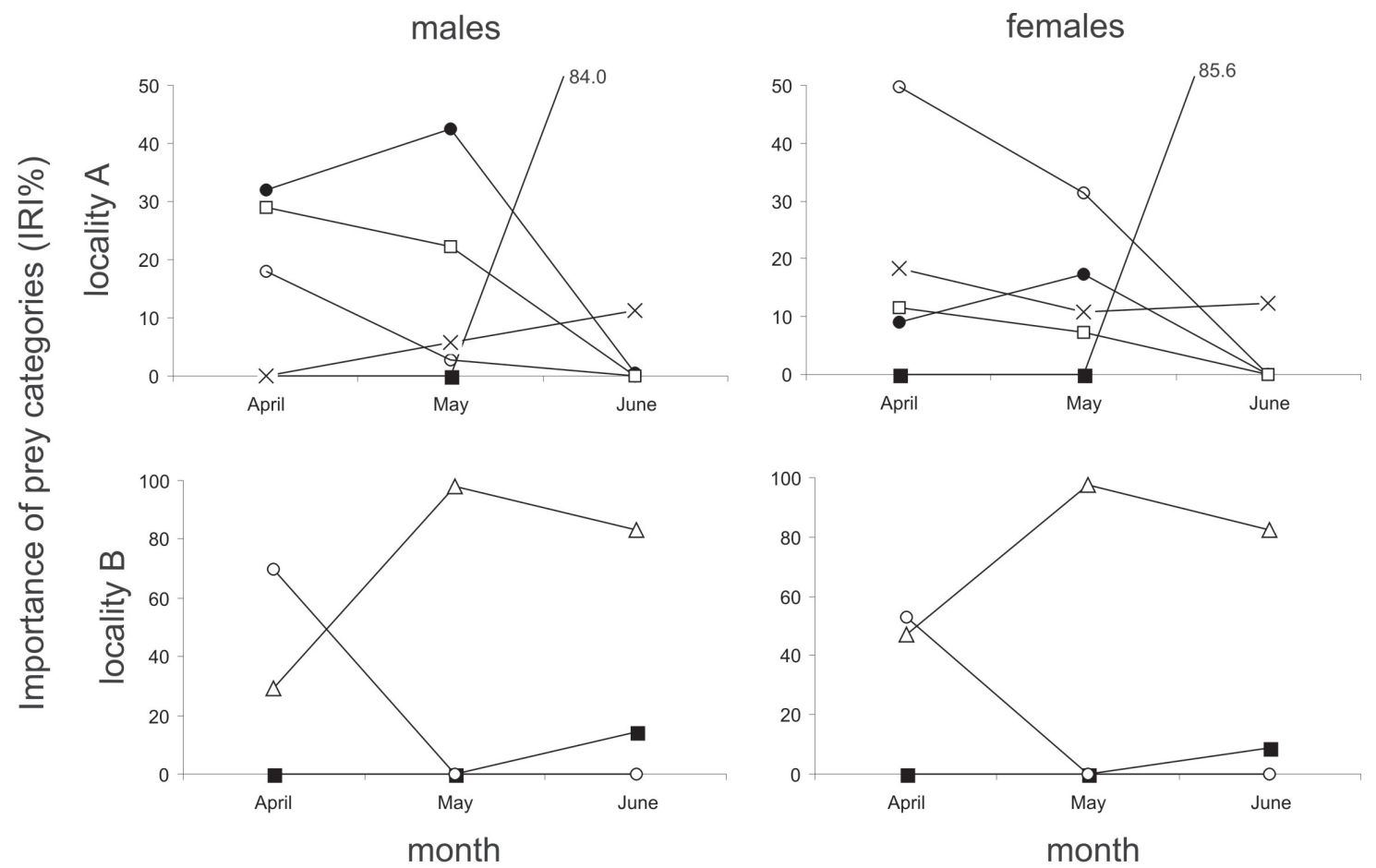

- Cladocera $\square$ Plecoptera Chironomidae ORana-eggs $\triangle$ Isopoda $\times$ Lumbricus

Fig. 1. - Changes in values of the index of relative importance (IRI\%) of the main prey categories consumed by alpine newts. 
TABLE 2

Differences in the number of consumed prey items between sexes of alpine newt from locality B (data from the months April, May, June pooled).

\begin{tabular}{lcccc}
\hline Prey & M mean (min.-max.) & F mean (min.-max.) & $\mathbf{Z}$ & $\mathbf{P}$ \\
\hline Turbellaria & 0.00 & $0.03(0-1)$ & 1.15 & 0.25 \\
Oligochaeta & $0.02(0-1)$ & $0.10(0-1)$ & 1.75 & 0.08 \\
Gastropoda & 0.00 & 0.00 & & \\
Bivalvia & 0.00 & 0.00 & & \\
Arachnida & 0.00 & $0.05(0-2)$ & 1.15 & 0.25 \\
Cladocera & $0.43(0-4)$ & $0.56(0-7)$ & 0.00 & 1.00 \\
Cyclopoida & $0.11(0-2)$ & $0.10(0-1)$ & 0.41 & 0.68 \\
Isopoda & $\mathbf{1 . 1 1}(\mathbf{0 - 6})$ & $\mathbf{1 . 8 5}(\mathbf{0 - 6})$ & $\mathbf{2 . 6 6}$ & $\mathbf{0 . 0 1}$ \\
Ephemeroptera larvae & 0.00 & 0.00 & & \\
Ephemeroptera pupae & $0.02(0-1)$ & 0.00 & -0.83 & 0.41 \\
Plecoptera nymfa & $0.02(0-1)$ & 0.00 & -0.83 & 0.41 \\
Megaloptera larvae & 0.00 & 0.00 & & \\
Trichoptera & 0.00 & $0.05(0-2)$ & 1.66 & 0.10 \\
Lepidoptera & 0.00 & 0.00 & & \\
Culicidae pupae & $0.09(0-1)$ & $0.05(0-1)$ & -0.45 & 0.65 \\
Chironomidae larvae & $0.07(0-1)$ & $0.03(0-1)$ & -1.01 & 0.31 \\
Chironomidae pupae & $0.02(0-1)$ & 0.00 & -0.83 & 0.41 \\
Coleoptera & $0.02(0-1)$ & $0.03(0-1)$ & 0.22 & 0.83 \\
Rana eggs & $0.46(0-9)$ & $0.23(0-9)$ & -1.48 & 0.14 \\
\hline
\end{tabular}

amphibian eggs (DENOËL \& ANDREONE, 2003; DENOËL \& DEMARS, 2008) are reported as the prey types most consumed. In the populations of the Czech Republic, important alpine newt prey include Lumbricus, Cladocera, Isopoda, Rana eggs and Ostracoda (RULÍK, 1993; KOPECKÝ et al., 2014).

The qualitative composition of prey items and their importance in the different sexes is constant within the species; in other words, males and females consume generally the same prey categories. Even Lumbricus, which was the largest prey type in our samples, was consumed by both sexes, regardless of the fact that females were about $15 \%$ larger than the males at both localities (KOPECKÝ et al., 2012a).

Generally, female alpine newts consumed more prey items than males during the breeding period (KOPECKÝ et al., 2012a). This was especially obvious for prey categories with the highest importance at the particular localities -
Rana eggs at locality A and Isopoda at locality B. Females also had a narrower niche breadth at both localities and during the whole aquatic season. Both these findings suggest that females are more sensitive to the trade-off between energy intake (from prey) and expenditure (spent while searching and hunting for prey). The metabolic cost of reproduction is probably higher for female alpine newts than for males, as was discovered in the case of ambystomatid salamaders (FINKLER \& CULLUM , 2002).

Trophic niche separation can be achieved by selection of different microhabitats, food resource partitioning or temporal segregation (SCHOENER 1974). Temporal segregation was not found in the species studied (MARTIN et al., 1989), both sexes exhibited diel flexibility in hunting activities (JOLY \& GIACOMA, 1992). Using different microhabitats is often described as a mechanism for the coexistence of different newt species of various sizes at the same locality (Joly \& GIACOMA, 1992; COVACIU-MARCOV 
TABLE 3

Levins' indices of niche breadth of alpine newts from the localities studied (A, B).

\begin{tabular}{clccc}
\hline & & April & May & June \\
\hline locality A & males & 0.277 & 0.217 & 0.018 \\
& females & 0.261 & 0.183 & 0.005 \\
locality B & males & 0.079 & 0.071 & 0.124 \\
& females & 0.057 & 0.057 & 0.103 \\
\hline
\end{tabular}

et al., 2010). On a subtle scale, intersexual resource partitioning is probably the key mechanism of niche separation (YAMAGUCHI et al., 2003). Intersexual resource partitioning is comparable with coexistence and feeding habits of paedomorphs and metamorphs of the same newt species, especially in shallow ponds (DENOËL \& ANDREONE, 2003; VignOLI et al., 2007). The relatively high prey niche overlap of sexes (as observed in this study) is explained as the consequence of high abundance and high availability of potential prey in an environment that obscures the competition relationship (GRIFFITHS, 1987). Due to absence of data about prey availability at the both localities studied, it is also possible that the diversity of preyed taxa was not sufficient to reveal general difference in prey selectivity of the sexes.

At locality B the trophic niche overlap was stable and high over the three months, while at locality A it was generally lower, especially during April and May. The diversity of taxa consumable by newts was probably higher at locality A where newts caught prey from 18 taxa, while at locality B prey were consumed from only 14 taxa. There was a comparatively high prey niche overlap in June, especially at locality A where both sexes consumed Cladocera almost exclusively.

Newts are traditionally recognized as generalist predators (FASOLA \& CANOVA, 1992). Generalists are characterized by having a niche breadth higher than 0.5 (MACARTHUR \& LEVINS, 1967). At both localities studied, niche breadth during each of the months was lower than 0.5. As is evident from changes in prey importance, newts opportunistically shift among preyed taxon, that is, utilize the most accessible prey in a given period. For example, the abundance of immobile and biomass-dense Rana eggs, as one of main categories at both localities under study, decreased as the reproductive season advanced. Conversely, at the end of the newt's reproductive period, newts ate more but smaller prey items, which appeared abundantly in ponds - mainly small crustaceans (this study) or aphids that fell on the water surface, as was found in a population from the Italian Alps (VIGNOLI et al., 2007).

The occurrence of the prey taxa is connected with the specific and diverse microhabitats in ponds (water surface, water column, aquatic plants, muddy bottom, etc.) (DENOËL \& JOLY, 2001), so newts must be able to switch between several hunting strategies and capture modes. Although there is no direct evidence from field studies, newts may search for food on land even during the breeding season, for example during movements between reproductive ponds (KOPECKÝ et al., 2010; KOPECKÝ et al., 2012b). Despite extensive morphological and physiological changes, newts can capture prey in the terrestrial environment due to behavioural plasticity, which compensates for the morphological constraints imposed by this water-terrestrial transition (HEISS et al., 2013). Hence niche breadth changes considerably during the breeding phase of newts.

\section{ACKNOWLEDGEMENTS}

I thank František Šusta who provided the material. Field work was carried out under permit number 8754/97-410/2453/97 from the Czech Ministry of the Environment. This study was supported by CIGA Project No. 20152007 of the Czech University of Life Sciences Prague. The English was corrected by Fred Rooks. 


\section{REFERENCES}

BeCK CA, IVerson SJ, Don Bowen W \& Blanchard W (2007). Sex differences in grey seal diet reflect seasonal variation in foraging behaviour and reproductive expenditure: evidence from quantitative fatty acid signature analysis. Journal of Animal Ecology, 76: 490-502.

BLANCKENHORN WU (2005). Behavioral causes and consequences of sexual size dimorphism. Ethology, 111: 977-1016.

COVACIU-Marcov SD, CicORT-LuCACIU AS, Mitrea I, SAs I, CAus AV \& Cupsa D (2010). Feeding of three syntopic newt species (Triturus cristatus, Mesotriton alpestris, Lissotriton vulgaris) from Western Romania. North-Western Journal of Zoology 6: 95-108.

DENOËL M \& JOLY P (2001). Adaptive significance of facultative paedomorphosis in Triturus alpestris (Amphibia, Caudata): resource partitioning in an alpine lake. Freshwater Biology, 46: 1387-1396.

DENOËL M \& ANDREONE F (2003). Trophic habits and aquatic microhabitat use in gilled immature, paedomorphic and metamorphic alpine newts (Triturus alpestris apuanus) in a pond in central Italy. Belgian Journal of Zoology, 133: 95-102.

DENOËL M \& DEMARS B (2008). The benefits of heterospecific oophagy in a top predator. Acta Oecologica, 34: 74-79.

Denoël M, IVANovic A, Dzukic G \& Kalezic ML (2009). Sexual size dimorphism in the evolutionary context of facultative paedomorphosis: insights from European newts. Evolutionary Biology, 9: 278.

FASOla M \& CANOVA L (1992). Feeding habits of Triturus vulgaris, T.cristatus and T.alpestris (Amphibia, Urodela) in the northern Apennines (Italy). Bollettino di Zoologia, 59: 273-280.

FERNER JW (1979). A review of marking techniques for amphibians and reptiles. Herpetological Circular, 9: 1-41.

FinKLER MS \& CULLUM KA (2002). Sex-related differences in metabolic rates and energy reserves in spring-breeding small-mouthed salamanders (Ambystoma texanum). Copeia 2002: 824-829.

GRIFFITHS RA (1987). Microhabitat and seasonal niche dynamics of Smooth and Palamate newts, Triturus vulgaris and Triturus helveticus, at a pond in mid-Wales. Journal of Animal Ecology, 56: 441-451.
GRIFFITHS RA (1996). Newts and Salamanders of Europe. Poyser and Poyser, London.

Heiss E, AERTS $\mathrm{P}$ \& VAN WASSENBERgh $\mathrm{S}$ (2013). Masters of change: seasonal plasticity in the prey-capture behaviour of the alpine newt Ichthyosaura alpestris (Salamandridae). Journal of Experimental Biology, 216: 4426-4434.

Heyer WR, DONNELly MA, MCDiarmid RW, HAYEK LC \& FOSTER MS (1994). Measuring and Monitoring Biological Diversity, Standard methods for Amphibians. Smithsonian Institution Press, Washington.

Hoeck PEA \& GARNER TWJ (2007). Female alpine newts (Triturus alpestris) mate initially with males signalling fertility benefits. Biological Journal of Linnean Society, 91: 483-491.

JOLY P \& GIACOMA C (1992). Limitation of similarity and feeding habits in three syntopic species of newts (Triturus, Amphibia). Ecography, 15: 401411.

KOPECKÝ O, VOJAR J \& DENOËL M (2010). Movements between aquatic habitats during a breeding season. Amphibia-Reptilia, 31: 109-116.

KOPECKÝ O, VOJAR J, ŠUSTA F \& REHÁK I (2011). Non-prey items in stomachs of alpine newts (Mesotriton alpestris, Laurenti). Polish Journal of Ecology, 59: 631-635.

KOPECKÝ O, VOJAR J, ŠUSTA F \& REHÁK I (2012a). Composition and scaling of male and female alpine newt (Mesotriton alpestris) prey, with related site and seasonal effects. Annales Zoologici Fennici, 49: 231-239.

KopeckÝ O, VoJAR J \& DenOËL M (2012b). Sex-specific effect of pool desiccation on the movement of alpine newts among breeding sites. Herpetozoa, 24: 127-134.

KOPECKÝ O, VOJAR J, ŠUSTA F \& REHÁK I (2014). Složení potravy čolka horského (Mesotriton alpestris) z vybraných lokalit České republiky. Př́roda Praha, 32: 185-195.

KopeckÝ O, NovÁK K, VoJAR J \& ŠUSTA F (accepted). Food composition of alpine newts (Ichthyosaura alpestris) during spring migration. North-Western Journal of Zoology.

KREBS CJ (1998). Ecological methodology. Benjamin Cummings, New York.

KRÜGER O (2005). The evolution of reversed sexual size dimorphism in hawks, falcons and owls: A comparative study. Evolutionary Ecology, 19: 467-486. 
Luiselli L, CAPIZZI D, FilipPi E, ANiBAldi C, Rugiero L \& CAPUla M (2007). Comparative diets of three populations of an aquatic snake (Natrix tessellata, Colubridae) from Mediterranean streams with different hydric regimes. Copeia, 2007: 426-435.

MACARTHUR RH \& LEVINS R (1967). The limiting similarity convergence and divergence of coexisting species. American Naturalist, 101: 377-385.

Mariano-Jelicich R, MADRID E \& FAVEROL M (2007). Sexual dimorphism and diet segregation in the black skimmer Rynchops niger. Ardea, 95: $115-124$.

OPATRNÝ E (1968). Př́śspěvek k poznání potravy našich vodních skokanů (Rana ridibunda Pallas, Rana esculenta Linné). Acta Upol Facultatis Rerum Naturalis - Biologica, 28: 133-139.

OPATRNÝ E (1980). Food sampling in live amphibians. Věstník Československé Společnosti Zoologické, 44: 268-271.

RULíK M (1993). Contribution to the knowledge of the diet of the newt, Triturus alpestris. Folia Zoologica, 42: 33-45.

SCHABETSBERGER R \& JERSABEK CD (1995). Alpine newts (Triturus alpestris) as top predators in a high-altitude karst lake: daily food cansumption and impact on the copepod Arctodiaptomus alpinus. Freshwater Biology, 33: 47-61.
SHetTy S \& SHINE R (2002). Sexual divergence in diets and morphology in Fijian sea snakes Laticauda colubrine. Australian Ecology, 27: $77-84$

SHINE R (1989). Ecological cause for the evolution of sexual dimorphism: a review of the evidence. Quaterly Review of Biology, 64: 419-461.

SCHOENER TW (1974). Resource partitioning in ecological communities. Science, 185: 27-39.

STATISTICA 12.0 (2012): Electronic statistics textbook. Statsoft, Tulsa.

Vignoli L, Bombi P, D'Amen M, Bologna MA (2007). Seasonal variation in the trophic niche of a heterochronic population of Triturus alpestris apuanus from the south-western Alps. Herpetological Journal, 17: 183-191.

YAMAGUCHI N, RUSHTON S, MACDONALD DW (2003). Habitat preferences of feral American mink in the Upper Thames. Journal of Mammalogy, 84: 1356-1373.

ZALEWSKI A (2007). Does size dimorphism reduce competition between sexes? The diet of male and female pine martens at local and wider geographical scales. Acta Theriologica 52: 237250.

Received: 16 November 2015

Accepted: 7 March 2016

Branch editor: Stuart Halse 